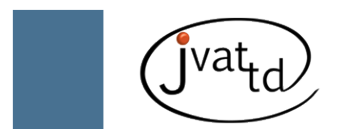

The Journal of Venomous Animals and Toxins including Tropical Diseases ISSN 1678-9199 | 2010 | volume 16 | issue 3 | pages 480-492

\title{
Crotalus durissus terrificus venom as a source of antitumoral agents
}

\author{
Soares MA (1), Pujatti PB (1), Fortes-Dias CL (2), Antonelli L (3), Santos RG (1)
}

(1) Laboratory of Radiobiology, Nuclear Technology Development Center, CDTN/CNEN, Belo Horizonte, Minas Gerais State, Brazil; (2) Laboratory of Molecular Biology and Bioinformatics, Ezequiel Dias Foundation, FUNED, Belo Horizonte, Minas Gerais State, Brazil; (3) Institute of Biological Sciences, Federal University of Minas Gerais, Belo Horizonte, Minas Gerais State, Brazil.

\begin{abstract}
The basic knowledge on neoplasms is increasing quickly; however, few advances have been achieved in clinical therapy against tumors. For this reason, the development of alternative drugs is relevant in the attempt to improve prognosis and to increase patients' survival. Snake venoms are natural sources of bioactive substances with therapeutic potential. The objective of this work was to identify and characterize the antitumoral effect of Crotalus durissus terrificus venom (CV) and its polypeptide, crotoxin, on benign and malignant tumors, respectively, pituitary adenoma and glioblastoma. The results demonstrated that $\mathrm{CV}$ possess a powerful antitumoral effect on benign (pituitary adenoma) and malignant (glioblastoma multiforme) tumors with $\mathrm{IC}_{50}$ values of $0.96 \pm 0.11 \mu \mathrm{g} / \mathrm{mL}$ and $2.15 \pm 0.2 \mu \mathrm{g} / \mathrm{mL}$, respectively. This antitumoral effect is cell-cycle-specific and dependent on extracellular calcium, an important factor for crotoxin phospholipase $\mathrm{A}_{2}$ activity. The CV antitumoral effect can be ascribed, at least partially, to the polypeptide crotoxin that also induced brain tumor cell death. In spite of the known CV nephrotoxicity and neurotoxicity, acute treatment with its antitumoral dose established in vitro was not found to be toxic to the analyzed animals. These results indicate the biotechnological potential of $C V$ as a source of pharmaceutical templates for cancer therapy.
\end{abstract}

Key words: Crotalus durissus terrificus venom, crotoxin, antitumoral effect, pituitary adenoma, glioblastoma multiforme.

\section{INTRODUCTION}

According to the World Health Organization (1), cancer, which accounts for 7 million deaths annually, ranks second, behind only cardiovascular disease, among causes of death by disease in most countries. Although brain tumors constitute only 1 to $2 \%$ of the tumors in adults, they have a poor prognosis and the patients' chance of survival generally is very low. Moreover, brain tumors represent one of the most common solid tumor in children, being responsible for $20 \%$ of childhood neoplasms (2).

Glioblastoma multiforme (GBM) is the most common malignant brain tumor. It can infiltrate diffusely into normal brain regions rendering total surgical extirpation impossible and effective local radiotherapy difficult and thus requiring other therapy forms (3). Another type of brain tumor is the pituitary adenoma, a benign tumor, which represents about $7 \%$ of primary brain tumors (4). Patients with pituitary adenoma can have hypersecretion of growth hormone that may induce the development of acromegaly (5). Although surgery remains the treatment of choice for most patients, only 20 to $50 \%$ of patients can achieve control of hormone activity. Currently, gamma knife radiosurgery is the predominant method of treating failed pituitary surgery. However, radiosurgery poses the risk of radiation damage to the visual pathways. Somatostatin analogues are used for acromegaly treatment also, 
although lifelong therapy is inconvenient and very expensive (6). For this reason, the development of alternative drugs is relevant in the attempt to improve prognosis and to increase the patients' chance of survival.

Snake venoms are natural sources of bioactive substances with therapeutic potential. The search for new drugs has indicated toxins from Crotalus durissus terrificus venom as inhibitors of cell adhesion, cell migration, epidermal tumor growth factor and metastases induced in experimental mice models (7).

Crotoxin (Crtx) is the main polypeptide isolated from $C$. durissus terrificus snake venom (CV) corresponding to $68 \%$ of CV total weight (8). Crotoxin $(24 \mathrm{kDa})$ is a $\beta$-neurotoxin consisting of a heterodimeric non-toxic non-enzymatic acidic protein $(\mathrm{CA})$ and a basic protein $(\mathrm{CB})$ with phospholipase $\mathrm{A}_{2}$ activity (9).

Previous reports have shown antitumoral effect of CV against tumor cells such as ovary carcinoma (CHO-K1) cells in vitro and Ehrlich tumor cells in vivo $(10,11)$. The antitumoral effect of CV has been mainly ascribed to Crtx.

Some authors have demonstrated that Crtx was cytotoxic to murine and human tumor cell lines in vitro including erythroleukemia, glioblastoma (U-87), mammary ductal (Hs 578T), lung (SKLU-1) and Lewis lung carcinoma and breast (MCF-7) tumor cells (12-15).

It has been shown that apoptosis and autophagy make distinct and differentiable contributions to the Crtx-induced cell death involved in the antitumoral effect $(15,16)$. Donato et al. (17) reported that the Crtx-induced cytotoxicity appears to be highly selective toward cell lines expressing a high density of epidermal growth factor receptors, but the mechanisms of this antitumoral effect are still unknown.

All these literature data strongly corroborate the finding of Plata et al. (18) that crotoxin complex is a cytotoxic agent. Although Crtx has been used with some success in the treatment of several patients with squamous skin and breast cancer, to the best of our knowledge, no product derived from $\mathrm{CV}$ or its components, such as Crtx, has achieved worldwide application in clinics indicating that further studies should be performed $(7,19)$.

The aim of this work was to identify the antitumoral effect of $C$. durissus terrificus venom and its polypeptide, crotoxin, on benign and malignant tumors such as pituitary adenoma and glioblastoma as well as to characterize the mechanisms of this antitumoral effect.

\section{MATERIALS AND METHODS}

\section{Reagents}

All chemicals used were of analytical grade.

\section{Crotalus Venom and Crotoxin}

C. durissus terrificus venom was obtained from the Ezequiel Dias Foundation (FUNED, Brazil) and crotoxin was purified according to Seki et al. (20).

\section{Cell Culture}

Rat glioma RT2 cells derived from Fischer 344 rats (kindly provided by Dr. William C. Broaddus, Department of Neurosurgery, Medical College of Virginia, Virginia Commonwealth University, Richmond, VA, USA) and GH3 cells (benign pituitary adenoma) obtained from the American Type Culture Collection (ATCC, USA) were maintained in Dulbecco's Modified Eagle's Medium (DMEM) (Gibco, USA), supplemented with $10 \%$ fetal bovine serum (FBS) (Cultilab, Brazil) and $50 \mathrm{U} / \mathrm{mL}$ penicillin, in a humidified atmosphere air $/ \mathrm{CO}_{2}(5 \% / 95 \%)$ at $37^{\circ} \mathrm{C}$.

\section{Cytotoxicity Assay}

Cytotoxicity was calculated by 3-(4,5-dimethyl2-thiazolyl)-2,5-diphenyl-2H-tetrazolium bromide (MTT) assay which measures the cellular metabolic viability (21). The cells were cultured in 96-well plates and, 12 hours after the incubation, they were treated with different concentrations of $\mathrm{CV}(0.1$ to $30 \mu \mathrm{g} / \mathrm{mL})$. Another group of cells were treated with increasing concentrations ( 0.5 to 200 $\mu \mathrm{g} / \mathrm{mL}$ ) of cisplatin (positive control), a metallic complex commonly used as an antineoplastic in the clinic. After each treatment period, the cells were washed with phosphate buffer saline (PBS), incubated with MTT $(0.5 \mathrm{mg} / \mathrm{mL})$, and formazan crystals were solubilized in dimethyl sulfoxide (DMSO). Absorbance was measured in a microplate reader at $570 \mathrm{~nm}$. $\mathrm{IC}_{50}$ values were calculated as the concentration of antitumoral compound evoking $50 \%$ cytotoxicity.

\section{Morphological Analysis}

The cells were placed on 96-well plates and treated with different concentrations of 
CV. Morphological changes were analyzed 48 hours before the treatment by contrast-phase microscopy (Nikon Eclipse TS100â, Japan).

\section{DAPI Staining Assay}

DNA alterations characteristic of apoptotic cells were detected by 4',6-diamidine-2'-phenylindole dihydrochloride (DAPI) staining. Cells were cultured on 96-well plates (Techno Plastic Products AG, Switzerland) and treated with CV for 48 hours. After the treatment, cells were washed with PBS and fixed with $70 \%$ methanol at room temperature for 30 minutes. Cells were incubated in $0.4 \mu \mathrm{g} / \mathrm{mL}$ DAPI (Sigma, USA) for one hour in the dark after washing with PBS. DNA alterations such as condensation and fragmentation were observed by fluorescence microscopy at 385-410 $\mathrm{nm}$ (excitation-emission wavelength).

\section{DNA Cell Cycle Analysis}

After 48 hours of treatment with different concentrations of $\mathrm{CV}$, cells were washed twice with cold PBS and fixed in ethanol $75 \%$ (v/v). Cells were washed once with PBS and resuspended in cold propidium iodide solution (PI $-50 \mu \mathrm{g} / \mathrm{mL}$ ) containing RNase A $(100 \mu \mathrm{g} / \mathrm{mL})$ in PBS for 30 minutes in the dark. Flow cytometry analysis was performed on a flow cytometry system (Becton Dickinson, USA). Population of cells containing sub-G1 DNA quantity was calculated as an estimation of the apoptotic cell population.

\section{Calcium and Growth Factor Influence on CV Antitumoral Effect}

C. durissus terrificus venom has proteins that secrete phospholipases ( $\mathrm{PLA}_{2} \mathrm{~s}$ ), enzymes that are activated by micromolar calcium concentrations (22). In order to verify whether extracellular $\mathrm{Ca}^{2+}$ and growth factor from serum play a role in the antitumoral activity of $\mathrm{CV}$, the $\mathrm{GH} 3$ and RT2 cells were treated with CV $(10 \mu \mathrm{g} / \mathrm{mL})$ in the absence of $\mathrm{Ca}^{+2}$ (PBS + FBS) or in the absence of FBS (DMEM without serum). Twenty-four hours after the treatment, cell survival was measured by the MTT test. The results were compared with the treatment effect at this same CV concentration in complete DMEM containing $\mathrm{Ca}^{+2}$ and FBS.

\section{Antitumoral Effect of the Main CV} Polypeptide: Crotoxin

The antitumoral effect of increasing crotoxin concentrations $(0.1$ to $100 \mu \mathrm{g} / \mathrm{mL})$ was evaluated by the cytotoxicity assay, morphological analysis and DAPI staining assay.

\section{Evaluation of the Acute Toxicity Produced by CV Antitumoral Dose Established In Vitro}

The antitumoral CV dose, observed in vitro, was calculated in micrograms of CV per square millimeter of treated area from the $\mathrm{IC}_{50}$ of MTT, after 24 hours of treatment $(3 \mu \mathrm{g} / \mathrm{mL})$. Given that $200 \mu \mathrm{L}$ of drug had been used in each well of a 96-well plate $\left(38.48 \mathrm{~mm}^{2}\right.$ area), the concentration $3 \mu \mathrm{g} / \mathrm{mL}$ represents a dose of $0.6 \mu \mathrm{g}$ of $\mathrm{CV}$ per well, equivalent to a final concentration of 0.016 $\mu \mathrm{g} / \mathrm{mm}^{2}$.

Once the in vitro $\mathrm{CV}$ antitumoral dose was calculated, a group of healthy animals were obtained in which a local treatment comprising a fake tumor of $18 \mathrm{~mm}^{2}$ was simulated for the toxicological analysis of the therapeutic CV dose. Twenty-four hours after treatment, blood samples were collected for the hematological analysis, and serum was separated for biochemical analysis (determination of blood urea, total proteins, alkaline phosphatase, albumin and creatine kinase). After this, the animals were sacrificed and the organs were taken for morphological analysis. All animal experimentation was performed according to the ethical protocol number $152 / 2007$ approved by the Ethics Committee on Animal Experimentation (CETEA).

\section{Statistical Analysis}

Data were expressed as means \pm S.D. Statistical significance of differences between means was determined by Student's t-test. Differences were considered significant at $p<0.05$.

\section{RESULTS}

\section{Cytotoxicity Assay}

The results showed that $\mathrm{CV}$ was cytotoxic in a dose- and time-dependent manner to both glioblastoma and pituitary tumor lineages. However, GH3 cells were about twice as sensitive to the CV cytotoxic effect than were RT2 cells, as indicated by the concentration values that inhibit $50 \%$ of cell survival $\left(\mathrm{IC}_{50}\right): 48$ hours after treatment, the $\mathrm{IC}_{50}$ was $0.96 \pm 0.11 \mu \mathrm{g} / \mathrm{mL}$ for GH3 cells and $2.15 \pm 0.20 \mu \mathrm{g} / \mathrm{mL}$ for RT2 cells (Table 1).

The highest CV concentrations used ( 5 to $30 \mu \mathrm{g}$ / $\mathrm{mL}$ ) reduced the survival of $\mathrm{GH} 3$ cells significantly 
Table 1. Cytotoxic effect of 48-hour treatment with CV and its main polypeptide, crotoxin, on brain tumor cells

\begin{tabular}{c|c|c}
\hline Compounds & $\mathrm{IC}_{50}$ & $(\mu \mathrm{g} / \mathrm{mL})$ \\
\hline $\mathrm{CV}$ & $\mathrm{GH}$ & $\mathrm{RT} 2$ \\
\hline Crotoxin & $0.96 \pm 0.11 \mu \mathrm{g} / \mathrm{mL}$ & $2.15 \pm 0.20 \mu \mathrm{g} / \mathrm{mL}$ \\
\hline Cisplatin & $>100.00 \mu \mathrm{g} / \mathrm{mL}$ & $>100.00 \mu \mathrm{g} / \mathrm{mL}$ \\
\hline
\end{tabular}

in the first six hours of treatment $( \pm 60$ to $75 \%$ reduction, $\mathrm{p}<0.01$ ) (not shown). The highest $\mathrm{CV}$ cytotoxic effect on these tumor cells occurred 144 hours after treatment with $1 \mu \mathrm{g} / \mathrm{mL}$ which was lethal for about $95 \%$ of the cells (Figure 1). For RT2 cells the maximum CV cytotoxic effect occurred 144 hours after the treatment with $5 \mu \mathrm{g} / \mathrm{mL}$, when no cells were found alive (data not shown).

\section{Morphological Analysis}

As shown in Figure 2 (A and B), GH3 and RT2 cells treated with CV for 48 hours presented visible morphological alterations, namely: irregularities in cellular shape, cell shrinkage and bleb formation, all characteristics of apoptosis. These results are indicative that the reduction of cell survival after the treatment with $\mathrm{CV}$, observed

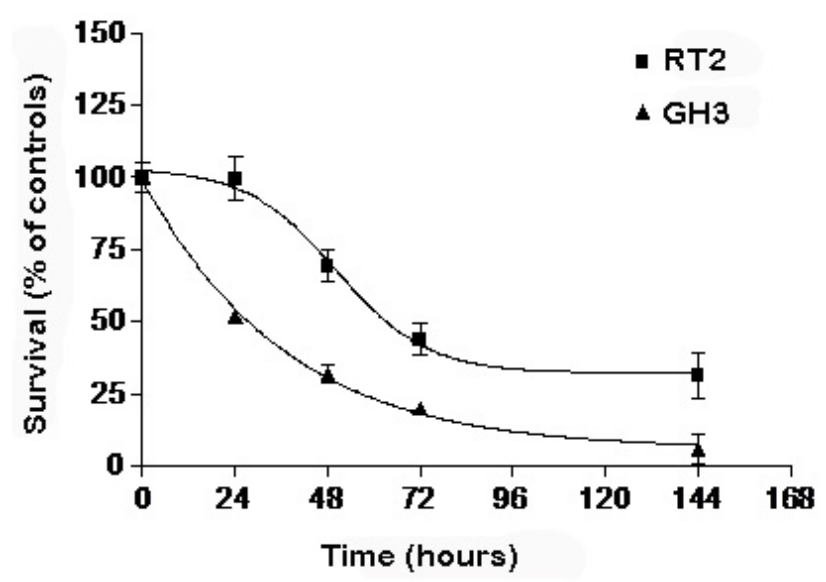

Figure 1. Kinetics of $\mathrm{CV}$ antitumoral effect on brain tumor cell lines. Brain tumor cells were treated with CV $(1 \mu \mathrm{g} / \mathrm{mL})$ for $24,48,72$ and 144 hours. Cell viability was determined by MTT assay. Results are presented as survival ratio compared with the control group (untreated cells). GH3 and RT2 cells were sensitive to $\mathrm{CV}$ in a time-dependent manner. in Figure 1 (A and B), occurred through apoptosis induction.

\section{DAPI Staining Assay}

Brain tumor cells treated with CV presented nuclear condensation, DNA fragmentation and perinuclear apoptotic body formation, all characteristics of apoptosis (Figure $3-\mathrm{A}$ and B).

\section{DNA Cell Cycle Analysis}

The treatment with $5 \mu \mathrm{g} / \mathrm{mL}$ of CV (48 hours) evoked significant increase $( \pm 17$-fold increase, $p$ $<0.01$ ) in the number of subG1 GH3 cells, which is indicative of apoptosis (Figure $4-\mathrm{A}$ ). In RT2 cells the CV treatment also evoked an increase $( \pm$ 4 fold increase, $\mathrm{p}<0.01$ ) of subG1 cells (Figure 4 B). Cells that did not suffer apoptosis accumulated in G1/G0 (Figure $4-\mathrm{B}$ ), suggesting cell cycle arrest, which prevented their progression in the cycle from the S, G2 and M phases. This arrest was probably due to an attempt to repair the damage evoked by CV treatment. However, this attempt was not successful since all RT2 cells had died 144 hours after the treatment with 3 to 10 $\mu \mathrm{g} / \mathrm{mL}$ of CV (data not shown).

\section{Calcium and Growth Factors Affect CV Antitumoral Activity}

The CV antitumoral effect on GH3 and RT2 cells was dependent on the presence of growth factors (FBS) (Figure 5 - A and B). The CV effect was about $45 \%$ less potent in the absence of serum than in its presence $(\mathrm{p}<0.05)$. This result suggests that the $\mathrm{CV}$ action is cell-cycle-dependent (more efficient in cells that are actively proliferating). However, the possibility that CV acted in the quiescent cells (G0 phase) cannot be ruled out, since $\mathrm{CV}$ did not lose its antitumoral activity. 

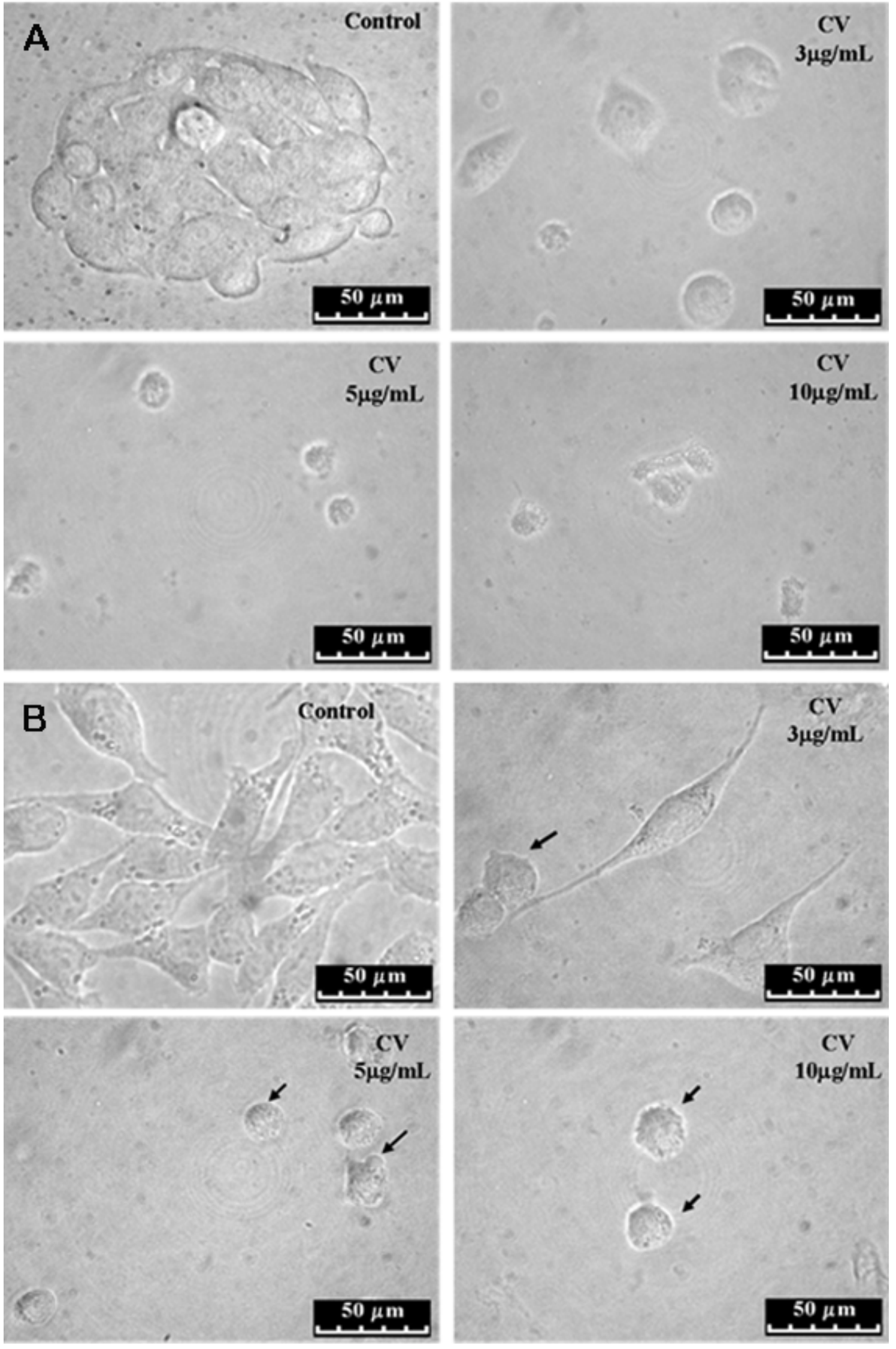

Figure 2. CV induces morphological changes in brain tumor cell lines. Photomicrographs from phasecontrast microscopy: (A) GH3 cells and (B) RT2 cells. Brain tumor cells were treated with different CV concentrations for 48 hours. Cell shrinkage and irregularity in cellular shape (indicated by arrows) were seen in the CV-treated cells. 

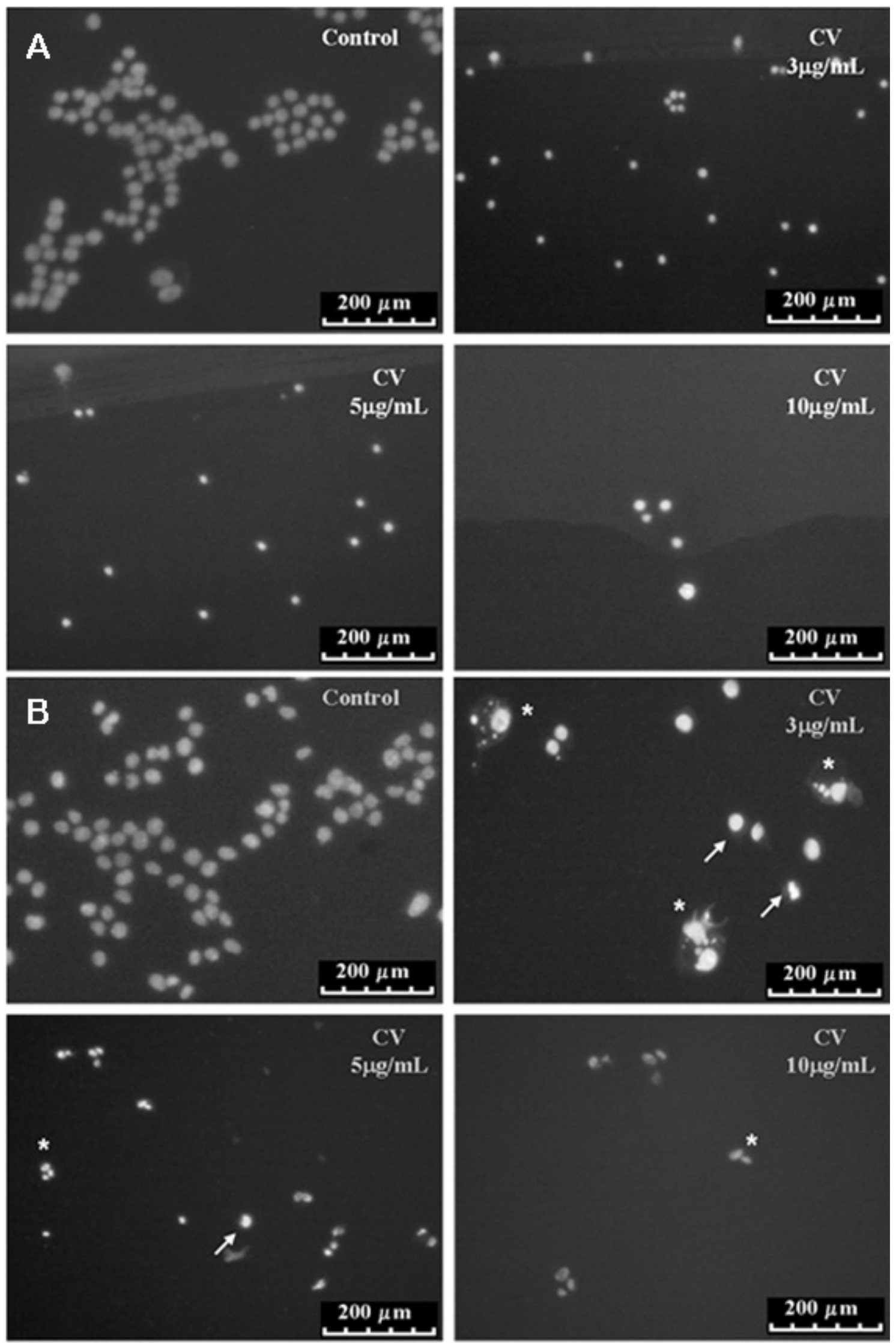

Figure 3. Cell death induced by CV: (A) GH3 cells and (B) RT2 cells. Brain tumor cells were treated with different $\mathrm{CV}$ concentrations for 48 hours. After the treatment the cells were stained with DAPI stain. Nuclear condensation (indicated by arrows) and apoptotic body formation (indicated by asterisks) were seen in the CV-treated cells. 
A

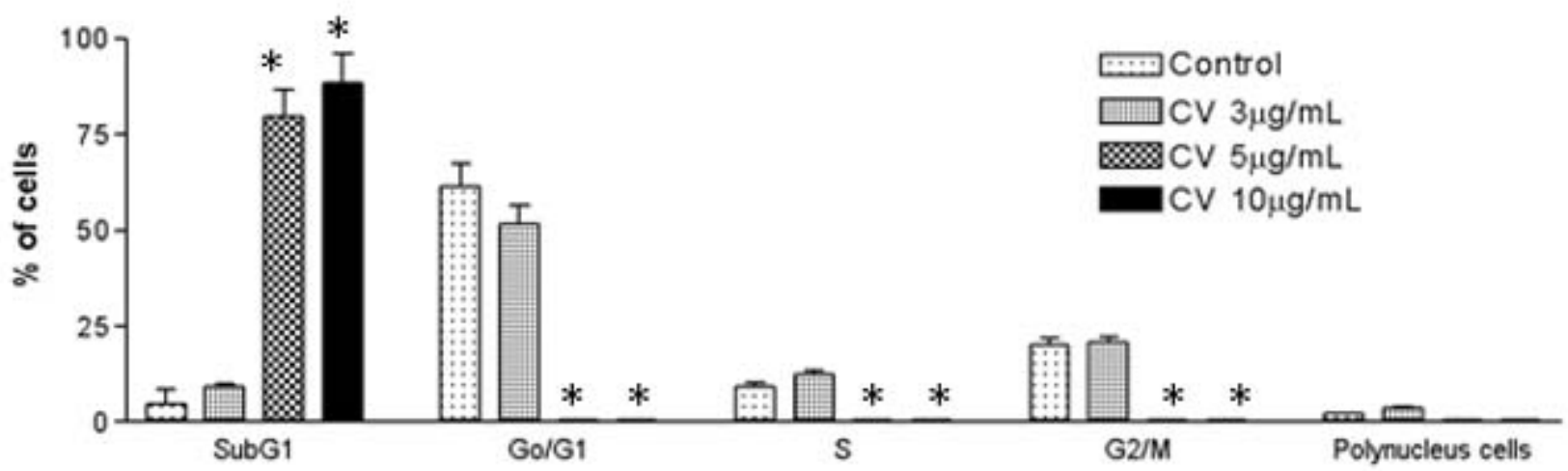

B

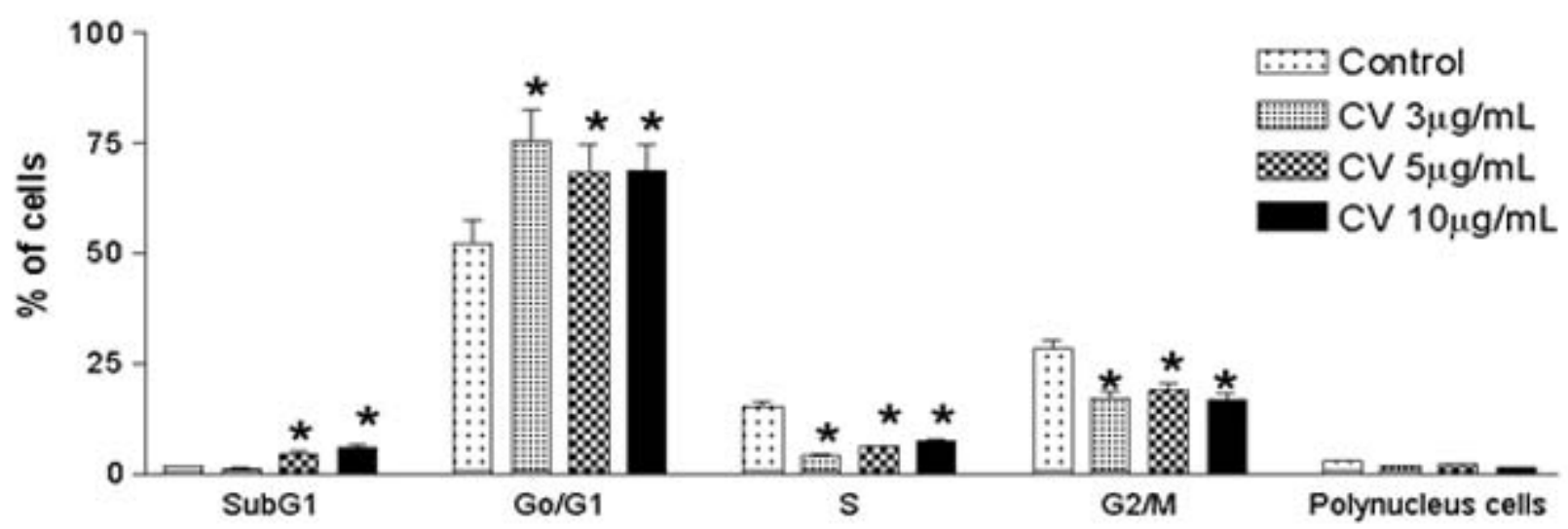

Figure 4. Flow cytometry analysis of DNA content in CV-treated cells: (A) GH3 cells and (B) RT2 cells. Brain tumor cells were treated with different CV concentrations for 48 hours. Cell cycle was analyzed by flow cytometry using propidium iodide. CV induced death and cell cycle arrest in brain tumor cells ( $\left.{ }^{*} p<0.01\right)$.

A

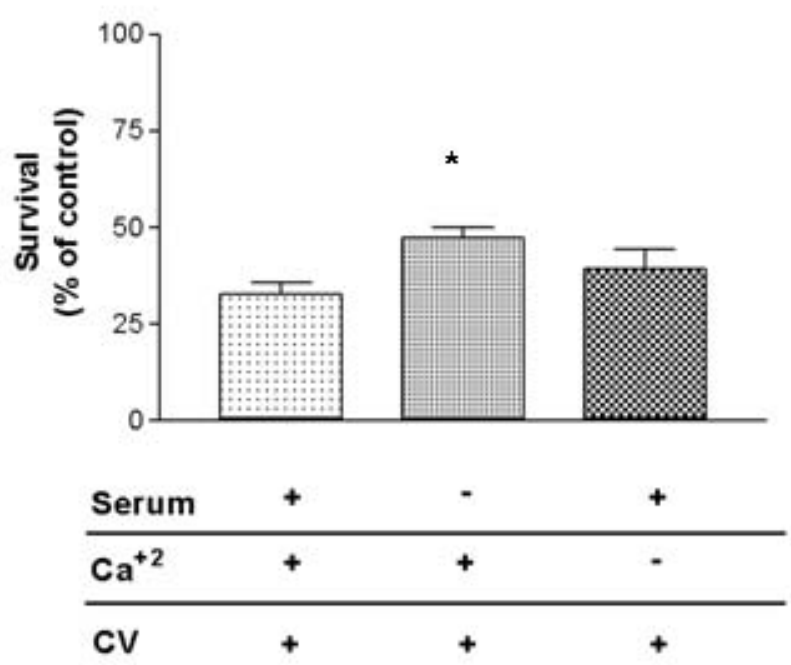

B

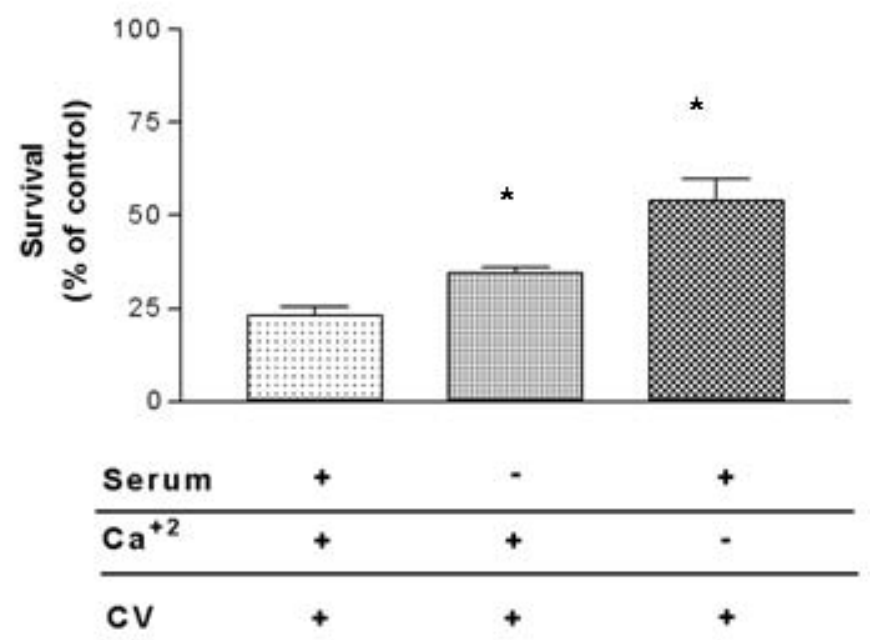

Figure 5. Calcium and growth factors influence on CV antitumoral effect: (A) GH3 cells and (B) RT2 cells. Brain tumor cells were treated with $10 \mu \mathrm{g} / \mathrm{mL}$ of CV for 48 hours in the presence and absence of calcium and FBS. In GH3 cells, the CV antitumoral effect was reduced only in the absence of serum. In RT2 cells, the $\mathrm{CV}$ antitumoral activity was reduced as in the absence of either serum or calcium ( $\left.{ }^{*} p<0.01\right)$. 

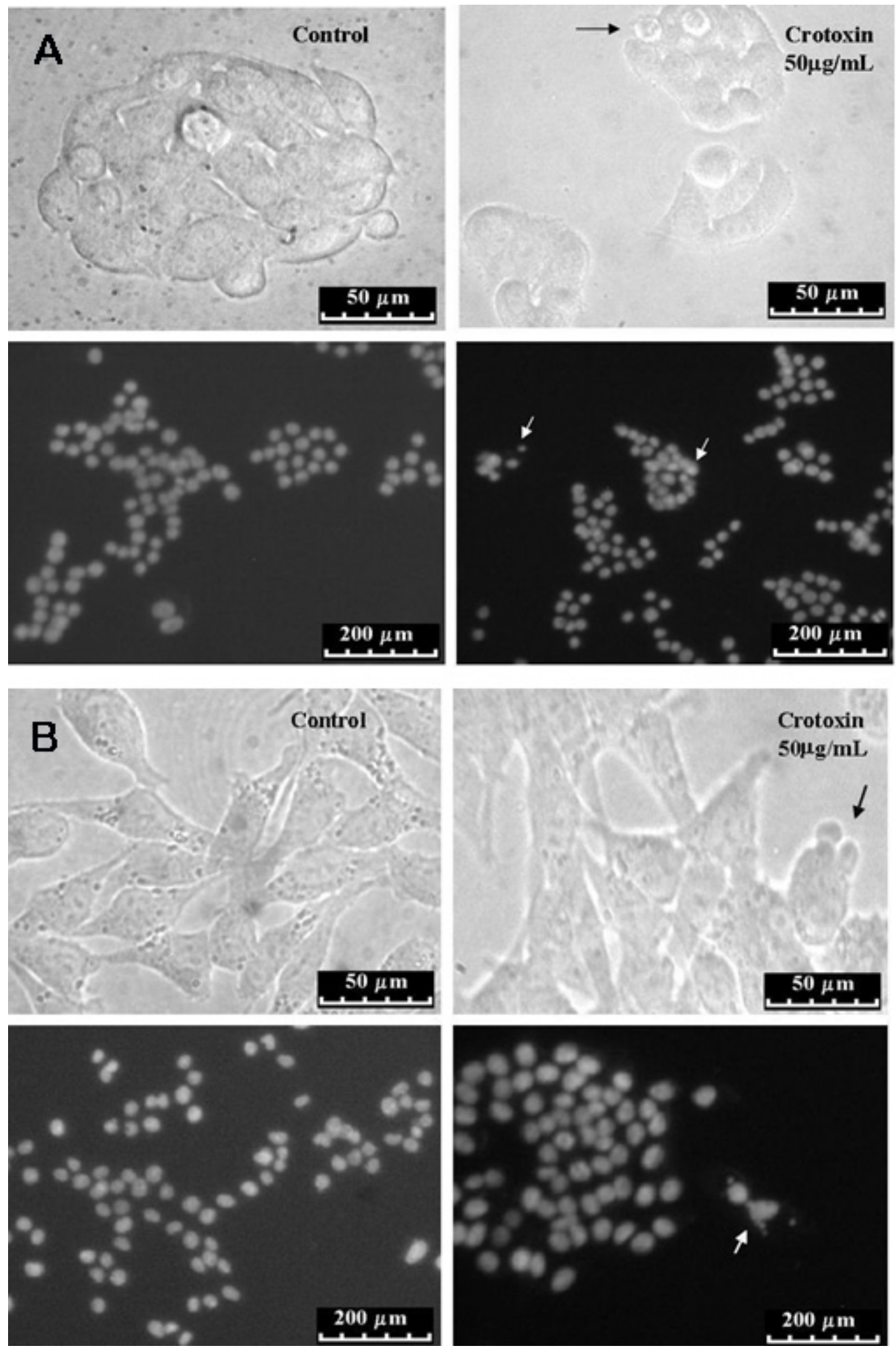

Figure 6. Crotoxin induces morphological changes and death in brain tumor cell lines: (A) GH3 cells and (B) RT2 cells. Brain tumor cells were treated with different crotoxin concentrations for 48 hours. Cell shrinkage, irregularity in cellular shape (indicated by black arrows), nuclear condensation and apoptotic body formation (indicated by white arrows) were seen in the crotoxin-treated cells. 

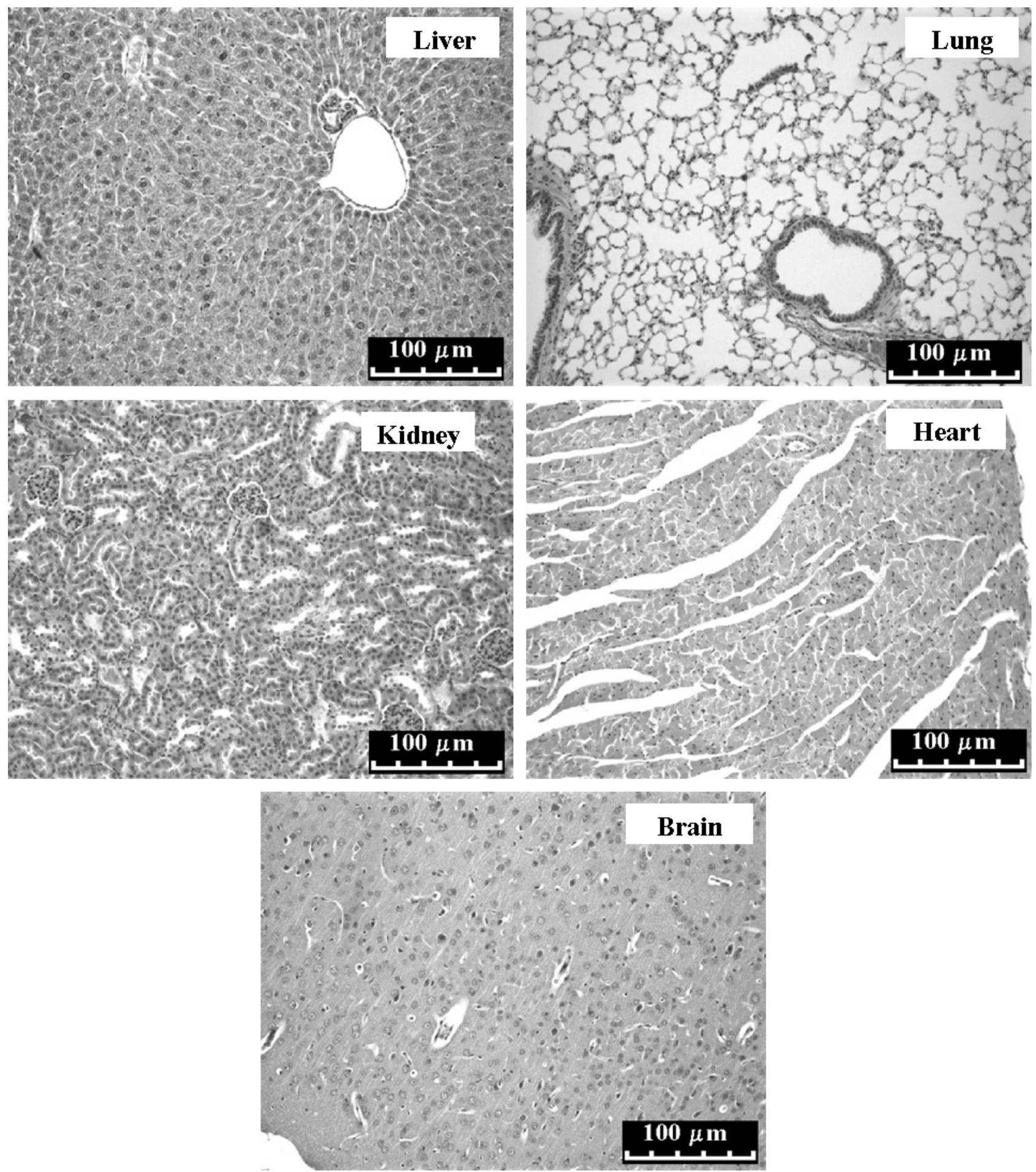

Figure 7. Liver, lung, kidney, heart and brain photomicrographs from a representative animal treated with the antitumoral CV dose established in vitro. No apparent morphological alteration was observed in the organs of the CV-treated animals. 
Table 2. Biochemical and hematological analysis of mice treated with the therapeutic CV dose established in vitro

\begin{tabular}{c|c|c}
\hline & Control group & Treated group \\
\hline Blood urea & $60.46 \pm 4.02 \mathrm{mg} / \mathrm{dL}$ & $59.25 \pm 6.85 \mathrm{mg} / \mathrm{dL}$ \\
\hline Total proteins & $7.18 \pm 0.39 \mathrm{mg} / \mathrm{dL}$ & $7.86 \pm 0.27 \mathrm{mg} / \mathrm{dL}$ \\
\hline Alkaline phosphatase & $209.10 \pm 30.86 \mathrm{U} / \mathrm{mL}$ & $219.70 \pm 40.50 \mathrm{U} / \mathrm{mL}$ \\
\hline Albumin & $2.17 \pm 0.13 \mathrm{~g} / \mathrm{dL}$ & $2.13 \pm 0.19 \mathrm{~g} / \mathrm{d}$ \\
\hline Creatine kinase & $23.00 \pm 2.00 \mathrm{U} / \mathrm{L}$ & $26.00 \pm 2.00 \mathrm{U} / \mathrm{L}$ \\
\hline Erythrocytes & $100.00 \pm 10.00 \%$ & $93.80 \pm 9.30 \%$ \\
\hline Lymphocytes & $67.70 \pm 3.06 \%$ & $69.60 \pm 14.00 \%$ \\
\hline Monocytes & $3.62 \pm 5.58 \%$ & $5.40 \pm 5.60 \%$ \\
\hline Granulocytes & $28.44 \pm 6.29 \%$ & $24.69 \pm 10.6 \%$ \\
\hline
\end{tabular}

Unlike GH3 cells, the CV antitumoral effect was partially calcium-dependent in RT2 cells. The effect of CV on these cells was about $135 \%$ lower in the absence of calcium than in its presence ( $p$ $<0.05)$.

\section{Antitumoral Effect of the Main CV Peptide: Crotoxin}

Crotoxin was cytotoxic to both GH3 and RT2 cells. After treatment with crotoxin, GH3 and RT2 presented irregularities in cellular shape, cell shrinkage, nuclear condensation and DNA fragmentation (Figure 6). These morphological alterations observed in crotoxin-treated cells indicate that, as in the case of $\mathrm{CV}$, this polypeptide induces cell death in brain tumors. However, treatment with the maximum concentration of $100 \mu \mathrm{g} / \mathrm{mL}$ was cytotoxic only to $14 \pm 0.7 \%$ of $\mathrm{GH} 3$ and $11 \pm 0.57 \%$ of RT2 cells $\left(\mathrm{IC}_{50}>100 \mu \mathrm{g} /\right.$ $\mathrm{mL})$.

\section{Evaluation of the Acute Toxicity Produced by Antitumoral CV Dose Established In Vitro}

The results showed that the blood cell number in treated animals remained equivalent to the one in controls. Moreover, plasmatic concentrations of blood urea, total proteins, alkaline phosphatase, albumin and creatine kinase were not significantly modified by $\mathrm{CV}$ treatment (Table 2) and no apparent histopathological alteration was found in the organs of treated animals (Figure 7).

\section{DISCUSSION}

An efficient antitumoral drug must be cytotoxic to the tumor cells without causing extreme damage to normal tissue (23). The results obtained in this work showed that $\mathrm{CV}$ was cytotoxic to two brain tumors lineages: a benign tumor of pituitary adenoma (GH3) and a malignant glioblastoma multiforme (RT2). Moreover, the CV cytotoxic effect was significantly higher than the effect evoked by cisplatin, a drug used clinically for tumor treatment $\left(\mathrm{CV}: \mathrm{IC}_{50}=0.96 \pm 0.11 \mu \mathrm{g} / \mathrm{mL}\right.$ against $\mathrm{GH} 3$ and $2.15 \pm 0.20 \mu \mathrm{g} / \mathrm{mL}$ against RT2, cisplatin: $\mathrm{IC}_{50}=5.01 \pm 0.50 \mu \mathrm{g} / \mathrm{mL}$ against $\mathrm{GH} 3$ and $4.96 \pm 0.40 \mu \mathrm{g} / \mathrm{mL}$ against RT2).

The CV-treated cells presented morphologic alterations including irregularities in cellular shape, cell shrinkage, nuclear condensation, DNA fragmentation and perinuclear apoptotic body formation, all characteristics of apoptosis. The analysis of the cell cycle also suggests that the treatment with CV evoked an increase of the apoptotic cells; moreover, this treatment induced a cell cycle arrest of RT2 cells in the G0/G1 phase. This fact is indicative that the sensory proteins (as ATM, ATR and DNA-PK) recognized the damage provoked by $\mathrm{CV}$ and tried to repair it. This repair attempt, however, seems not to be successful since, as demonstrated by the MTT test, all RT2 cells died 144 hours after CV treatment.

Apoptosis of tumor cells induced by $\mathrm{CV}$ also was recently demonstrated by Tamieti et al. (10) 
in ovarian carcinoma cells (CHO-K1). These authors suggested that $\mathrm{CV}$ induced apoptosis in $\mathrm{CHO}-\mathrm{K} 1$ cells through the mitochondrial pathway associated with the death promoter $\mathrm{Bcl}-2$ (Bad). $\mathrm{CHO}-\mathrm{K} 1$ cells possess the mutant P53 gene and, for this reason, do not possess the G1 checkpoint in the cell cycle (24). Probably, the Bad activation, in $\mathrm{CHO}-\mathrm{K} 1$ cells treated with CV, was mediated by $\mathrm{p} 53$ protein in G2 phase. The glioblastoma multiforme cells used in our experiments (RT2) possess wild type p53, which enables the DNA damage repair at G1/G2 checkpoints (25-27). We observed that the treatment of these p53 wild type cells with CV induced cell damage that activated cell cycle arrest in the G1 phase and induced apoptosis.

Taken together, the literature and the present data indicate that $\mathrm{CV}$ is capable of inducing apoptosis after cell cycle arrest in the G1 and G2 phases in the cell lines investigated in this work. Despite this, the induction of authophagy cannot be ruled out when using breast cancer cells as described by Yan et al. (15).

Growth factors are essential for cell proliferation. In the absence of these factors, cells in G1 leave the cell cycle and stay in G0 (quiescent phase), where cell metabolism is reduced and cell growth is absent. The quiescent cells can return to the cycle since there is growth stimulation (28). Antineoplastic agents can be cell-cycle-specific, more efficient in cells that are proliferating actively, or cell-cycle-unspecific, that is, possess effectiveness independent of the cell proliferation rate. Our results indicate that $\mathrm{CV}$ is cell-cyclespecific.

In the absence of growth factors (FBS), the CV cytotoxicity was about $45 \%$ lower than when they were present $(p<0.01)$. However, the possibility of CV acting in the G0 phase cannot be ruled out since, although less powerful, $\mathrm{CV}$ was cytotoxic to tumor cells in serum's absence. In addition to its dependence on growth factors, the CV cytotoxic effect was also dependent on the extracellular $\mathrm{Ca}^{+2}$ in RT2 cells. The previously described importance of $\mathrm{Ca}^{+2}$ in triggering apoptosis signals and the presence of calcium channels in GH3 and RT2 cells were also corroborated in the present work (29-31). The reduced CV cytotoxic effect in the absence of extracellular calcium probably occurred because the bioactive components, whose activity is calcium-dependent (such as phospholipases and metalloproteases), were not activated.

The main $\mathrm{CV}$ polypeptide, crotoxin, also induced cell death of brain tumor cells as demonstrated by the morphological alterations and DNA degradation. CV $(10 \mu \mathrm{g} / \mathrm{mL})$ was cytotoxic to all GH3 and RT2 cells, 144 hours after treatment. This $\mathrm{CV}$ concentration contains approximately $6.8 \mu \mathrm{g} / \mathrm{mL}$ of Crtx (8). Some authors demonstrated that Crtx was cytotoxic to a variety of murine and human tumor cell lines in vitro including erythroleukemia, lung (SK-LU-1), mammary ductal (Hs 578T), glioblastoma (U-87 $\mathrm{MG}$ ) and breast (MCF7) tumor cells (13, 15-17). In the present work, at the maximum concentration used, $100 \mu \mathrm{g} / \mathrm{mL}$, Crtx caused only mild cytotoxic effect to the brain tumor cells, suggesting that Crtx probably is not the main antitumoral component of $\mathrm{CV}$, at least in relation to these cell lines. Snake venoms are constituted by a mixture of biologically active substances, each bioactive component of which can exert its activity separately or with other components $(32,33)$. Crotamine, for example, can activate proteases and phospholipases $A_{2}$, indicating that it is capable of intensifying crotoxin activity (34). Studies using other CV polypeptides are necessary to identify whether they have some component more effective than $\mathrm{Crtx}$ in $\mathrm{CV}$ antitumoral action.

The identification and characterization of the antitumoral effect of $\mathrm{CV}$ indicated its therapeutical potential. In the development of new pharmaceuticals, toxicological studies are essential to evaluate possible adverse effects. The toxicological studies demonstrated that the administration of $\mathrm{CV}$ antitumoral dose, established in vitro $\left(0.016 \mu \mathrm{g} / \mathrm{mm}^{2}\right.$ of tumoral mass), did not evoke acute toxic effects; no histopathological or functional alteration was observed in treated animals. Brigatte (35) also demonstrated that a five-day crotoxin treatment $(18 \mu \mathrm{g})$ inhibited the Walker 256 tumor (mammary carcinosarcoma) growth with no histopathological alterations in the analyzed animals. These results are encouraging and support the safe use of some CV components as a plataform for the development of therapeutic antitumor drugs. Novais et al. (36) has successfully labeled Crtx with ${ }^{99}$ technetium $\left.{ }^{(99 \mathrm{~m}} \mathrm{Tc}\right)$, a radioisotope commonly used in diagnostic imaging, and the labeled molecule was proven useful for biodistribution and imaging studies. It remains to be demonstrated whether compounds derived from CV can also be useful as modeling tools for diagnostic imaging. 


\section{CONCLUSIONS}

In this work, it was possible to identify and characterize the $\mathrm{CV}$ antitumoral effect on benign and malignant tumors. This antitumoral effect is probably mediated by apoptosis induction, is cell-cycle-specific and dependent on extracellular calcium, an important factor for venom components including metalloproteases and phospholipases $\mathrm{A}_{2}$. The $\mathrm{CV}$ antitumoral effect can be ascribed, at least partially, to the polypeptide crotoxin, which also induced brain tumor cell death. Moreover, the CV antitumoral dose established in vitro evoked no significant toxicity in vivo. These results strongly indicate the use of $\mathrm{CV}$ components as template sources to develop pharmaceuticals for low-toxicity tumor therapy.

\section{ACKNOWLEDGMENTS}

This research was supported by CDTN/CNEN. M. A. Soares and P. B. Pujatti were fellowship students of The National Council for Scientific and Technological Development (CNPq) and The State of Minas Gerais Research Foundation (FAPEMIG), respectively.

\section{COPYRIGHT}

(C) CEVAP 2010

\section{SUBMISSION STATUS}

Received: January 11, 2010.

Accepted: May 11, 2010.

Abstract published online: June 7, 2010.

Full paper published online: August 31, 2010.

\section{CONFLICTS OF INTEREST}

There is no conflict.

\section{FINANCIAL SOURCE}

Nuclear Technology Development Center (CDTN/CNEN), The National Council for Scientific and Technological Development (CNPq), National Institute of Science and Technology of Molecular Medicine (INCT-MM) and The Minas Gerais Research Foundation (FAPEMIG).

\section{ETHICS COMMITTEE APPROVAL}

The present study was approved by the Ethics Committee on Animal Experimentation (CETEA) of the Federal University of Minas Gerais.

\section{CORRESPONDENCE TO}

RAQUEL GOUVÊA DOS SANTOS, Av. Antonio Carlos, 6627, Pampulha, Belo Horizonte, MG, 31.270-901, Brasil. Phone: +55 31 30693177. Fax: +553130693356. Email: santosr@cdtn.br.

\section{REFERENCES}

1. World Health Organization (WHO) [homepage on the Internet]. [updated 2009 Jun 20; cited 2009 Jun 20]. Available from: http://www.who.int / cancer.

2. Perez CA, Brady LW. Principles and practice of radiation oncology. Philadelphia: Lippincott-Raven Publisher; 1997.

3. Bernstein M, Berger MS. Neuro-oncology: the essentials. New York: Thieme Medical Publishers; 2004. 508 p.

4. American Brain Tumor Association. Brain Tumor Basics. In: A Primer of Brain Tumors. 8th ed. Des Plaines: American Brain Tumor Association; 2004. Available from: http://www.abta.org/siteFiles/SitePages/ E2E7B6E1D9BBEAD2103BCB9F2C80D588.pdf.

5. Donangelo I, Gadelha M. Bases moleculares dos adenomas hipofisários com ênfase nos somatotropinomas. Arq Bras Endocrinol Metabol. 2004;48(4):464-79.

6. Abosch A, Tyrrell JB, Lamborn KR, Hannegan LT, Applebury CB, Wilson CB. Transsphenoidal microsurgery for growth hormone-secreting pituitary adenomas: initial outcome and long-term results. J Clin Endocrinol Metab. 1998;83(10):3411-8.

7. Cura JE, Blanzaco DP, Brisson C, Cura MA, Cabrol R, Larrateguy L, et al. Phase I and pharmacokinetics study of crotoxin (Cytotoxic PLA2, NSC-624244) in patients with advanced cancer. Clin Cancer Res. 2002;8(4):1033-41.

8. da Silva MH, Bier OG. Titration of antiserum to South American rattlesnake (Crotalus durissus terrificus) venom by measuring inhibition of phospholipase $A_{2}$ activity. Toxicon. 1982;20(3):563-9.

9. Hendon RA, Fraenkel-Conrat H. Biological roles of the two components of crotoxin. Proc Natl Acad Sci USA. 1971;68(7):1560-3.

10. Tamieti BP, Damatta RA, Cogo JC, Da Silva NS, Mittmann J, Pacheco-Soares C. Cytoskeleton, endoplasmic reticulum and nucleus alterations in CHO-K1 cell line after Crotalus durissus terrificus (South American rattlesnake) venom treatment. J Venom Anim Toxins incl Trop Dis. 2007;13(1):56-68.

11. da Silva RJ, Fecchio D, Barraviera B. Effect of Crotalus durissus terrificus (Laurenti, 1768) venom on the evolution of Ehrlich ascites tumor. J Venom Anim Toxins. 1997;3(2): 324-41.

12. Corin RE, Viskatis LJ, Vidal JC, Etcheverry MA. Cytotoxicity of crotoxin on murine erythroleukemia cells in vitro. Investig New Drugs. 1993;11(1):11-5.

13. Rudd CJ, Viskatis LJ, Vidal JC, Etcheverry MA. In vitro comparison of cytotoxic effects of crotoxin in three human tumors and a normal human epidermal keratinocyte cell line. Investig New Drugs. 1994;12(3):183-4. 
14. Newman RA, Vidal JC, Viskatis LJ, Johnson J, Etcheverry MA. VRCTC-310 - a novel compound of purified animal toxins separates antitumor efficacy from neurotoxicity. Investig New Drugs. 1993;11(23):151-9.

15. Yan $\mathrm{CH}$, Yang YP, Qin ZH, Gu ZL, Reid P, Liang ZQ. Autophagy is involved in cytotoxic effects of crotoxin in human breast cancer cell line MCF-7 cells. Acta Pharmacol Sin. 2007;28(4):540-8.

16. Yan $\mathrm{CH}$, Liang ZQ, Gu ZL, Yang YP, Reid P, Qin $\mathrm{ZH}$. Contributions of autophagic and apoptotic mechanisms to CrTX-induced death of K562 cells. Toxicon. 2006;47(5):521-30.

17. Donato NJ, Martin CA, Perez M, Newman RA, Vidal JC, Etcheverry MA. Regulation of epidermal growth factor receptor activity by crotoxin, a snake venom phospholipase $\mathrm{A}_{2}$ toxin. A novel growth inhibitory mechanism. Biochem Pharmacol. 1996;51(11):153543.

18. Plata GJH, Costa LA, Coni CM, Vidal JC, inventors; Ventech Research, Inc., assignee. Crotoxin complex as cytotoxic agent. United States patent US 5164196. 1992 Nov 17. Available from: http://www.freepatentsonline. com/5164196.html.

19. Costa LA, Miles H, Araujo CE, Gonzalez S, Villarrubia VG. Tumor regression of advanced carcinomas following intra-and/or peri-tumoral inoculation with VRCTC-310 in humans: preliminary report of two cases. Immunopharmacol Immunotoxicol. 1998;20(1):15-25.

20. Seki C, Vidal JC, Barrio, A. Purification of gyroxin from a South American rattlesnake (Crotalus durissus terrificus) venom. Toxicon. 1980;18: 235-47.

21. Plumb JA, Miloroy R, Kaye SB. Effects of the $\mathrm{pH}$ dependence of 3-[4,5-dimetiltiazol-2-il]-2,5-difeniltetrazolium bromide-formazan absorption on chemosensitivity determined by a novel tetrazoliumbased assay. Cancer Res. 1989;49(16):4435-40.

22. Akiba S, Sato T. Cellular function of calciumindependent phospholipase $\mathrm{A}_{2}$. Biol Pharm Bul. 2004;27(8):1174-8.

23. Vorherr H. Adjuvant chemotherapy of breast cancer: hope - reality - hazard? Klin Wochenschr. 1984;62(4):149-61.

24. $\mathrm{Hu} \mathrm{T}$, Miller $\mathrm{CM}$, Ridder GM, Aardema MJ. Characterization of p53 in Chinese hamster cell lines CHO-K1, CHO-WBL, and CHL: implications for genotoxicity testing. Mutat Res. 1999;426(1):51-62.
25. Broaddus WC, Liu Y, Steele LL, Gillies GT, Lin PS, Loudon WG, et al. Enhanced radiosensitivity of malignant glioma cells after adenoviral p53 transduction. J Neurosurg. 1999;91(6):997-1004.

26. Innocente SA, Abrahamson JL, Cogswell JP, Lee JM. p53 regulates a G2 checkpoint through cyclin B1. Proc Natl Acad Sci USA. 1999;96(5):2147-52.

27. Attardi LD, de Vries A, Jacks T. Activation of the p53dependent G1 checkpoint response in mouse embryo fibroblasts depends on the specific DNA damage inducer. Oncogene. 2004; 23(4):973-80.

28. Israels ED, Israels LG. The cell cycle. Oncologist. 2000;5(6):510-3.

29. Orrenius S, Zhivotovsky B, Nicotera P. Regulation of cell death: the calcium-apoptosis link. Nat Rev Mol Cell Biol. 2003;4(7):552-65.

30. Gouvêa dos Santos R, Soares MA, Cruz JS, Mafra $\mathrm{R}$, Lomeo $\mathrm{R}$, Cordeiro $\mathrm{MN}$, et al. Tx1, from Phoneutria nigriventer spider venom, interacts with dihydropyridine sensitive-calcium channels in GH3 cells. J Radio Nucl Chem. 2006;269(3):585-9.

31. Latour I, Louw DF, Beedle AM, Hamid J, Sutherland GR, Zamponi GW. Expression of T-type calcium channel splice variants in human glioma. Glia. 2004;48(2):1129.

32. Bercovici D, Chudziniski AM, Dias VO, Esteves MI, Hiraichi E, Oishi NY, et al. A systematic fractionation of Crotalus durissus terrificus venom. Mem Inst Butantan. 1987; 49(3):69-78.

33. Rangel-Santos A, Lima C, Lopes-Ferreira M, Cardoso DF. Immunosuppressive role of principal toxin (crotoxin) of Crotalus durissus terrificus venom. Toxicon. 2004;44(6):609-16.

34. Mancin AC, Soares AM, Andrião-Escarso SH, Faça VM, Greene LJ, Zuccolotto S, et al. The analgesic activity of crotamine, a neurotoxin from Crotalus durissus terrificus (South American Rattlesnake) venom: a biochemical and pharmacological study. Toxicon. 1998; 36(12):1927-37.

35. Brigatte P. Efeito antinociceptivo do veneno de Crotalus durissus terrificus sobre a dor de cancer em ratos. Inibição do crescimento tumoral pela crotoxina [dissertation]. São Paulo: Faculdade de Medicina Veterinária e Zootecnia da Universidade de São Paulo; 2005. $151 \mathrm{p}$.

36. Novais CM, Pujatti PB, Castro MSA, Soares, MA, Simal C, Lima ME, Santos R G. Technetium-99m radiolabeling of crotoxin as a tool for biodistribution studies. J Radio Nucl Chem. 2006; 269(3):591-595. 